\title{
Urban management: Addressing the housing and utility challenge
}

\author{
Oksana Nikitina ${ }^{1 \mathrm{a}}$, Elena Alpatova ${ }^{1}$, Elena Shershneva $^{1}$, and Konstantin Rutkauskas ${ }^{1}$ \\ ${ }^{1}$ Ural State University, 620002, Yekaterinburg, Russia
}

\begin{abstract}
The authors have studied the three aspects of urban management: apartment buildings, major repair management, requirements for facility management companies to be licensed and waste management. The paper presents all the mentioned above aspects and possible negative circumstances and proposes solutions to the problems.
\end{abstract}

Urban development is due to the potential of accumulated professional experience, resources, communication. When resources are depleted, the experts begin to think about changing strategic priorities. Large cities have a strong attraction to the life currents of civilization. The rapid development of urban space means the formation of a special "spirit" of the agglomeration, filled with contra

The driver of urban growth was the "boom" of housing in metropolitan areas. For example, more than 1 million square meters were erected of new housing each year in the Yekaterinburg. However, geopolitical events have led today to the classical "crisis of overproduction" and the rise of the imbalance "demand - offer" [1]. Falling demand market can not completely "absorb" large-scale urban development projects.

In this context, it is time to shift the focus from programs "increase in square meters" on the quality of urban management procedures that would ensure the survival of the urban economy in a period of economic fluctuations.

During the 2014-2015 three approaches to the transformation of urban economy management have been developed. The first innovation is associated with the financial support of the "heavy" direction of Housing and Communal Services (HCS) - overhaul of buildings [2]. The second innovation concerns the scope of control and supervision over the management control of companies (CC) [3]. The third innovation is the new concept in the cleaning of household waste [4].

Innovation 1. Introduction fee overhaul. Based on the analysis of the features of municipal services sphere management authors have identified trends in the development of management innovations and proposed measures for their improvement.

At the beginning of 2016, there were 15 cities with "millionaire" in Russia [5]. This is metropolis with its social, cultural, ecological features. Along with intelligent architectural forms, creative design projects landscapes of modern cities today clouded view of houses is not a presentable appearance. The average specific gravity of the problem in the general fund housing volume is shown in Table 1. As a part of the problem fund dilapidated and emergency housing.

${ }^{a}$ Corresponding author: elen-kon@yandex.ru 
Dilapidated housing is not only disfigures architectural image of the city, but also requires the cost of maintaining accident-free "status." The experts found the consequences more dramatic order. Miserable habitat destruction is the health, social relations and personality. This is a very dangerous type of destruction: it quickly becomes irreversible. Bio-psycho-social disorders appear in the structure of personality.

The man, who sinks to the bottom of life, almost can not restore the previous level of welfare.

Table 1. The share of problematic housing in the total housing stock of the Russian Federation, as a percentage [5]

\begin{tabular}{|l|c|c|c|c|}
\hline \multicolumn{1}{|c|}{ Regions } & $\mathbf{2 0 1 0}$ & $\mathbf{2 0 1 2}$ & $\mathbf{2 0 1 3}$ & $\mathbf{2 0 1 4}$ \\
\hline Russian Federation & 3,08 & 3 & 2,8 & 2,69 \\
\hline Central Federal District & 1,92 & 1,8 & 1,73 & 1,66 \\
\hline Moscow & 0,33 & 0,4 & 0,38 & 0,39 \\
\hline Northwestern Federal District & 3,28 & 3,2 & 2,6 & 2,36 \\
\hline Saint Petersburg & 0,65 & 0,4 & 0,39 & 0,02 \\
\hline Southern Federal District (from 2010) & 2 & 1,8 & 1,74 & 1,59 \\
\hline North Caucasian Federal District & 6,75 & 6,5 & 6,59 & 6,54 \\
\hline Volga Federal District & 2,48 & 2,5 & 2,43 & 2,41 \\
\hline Ural Federal District & 3,09 & 3,3 & 3 & 3,06 \\
\hline Kurgan region & 5,73 & 5,7 & 5,47 & 5,5 \\
\hline Sverdlovsk region & 1,86 & 1,9 & 1,97 & 2 \\
\hline Tyumen region & 5,75 & 6,4 & 5,32 & 5,57 \\
\hline Khanty-Mansi Autonomous District & 6,96 & 7,3 & 6,88 & 7,42 \\
\hline Yamalo-Nenets Autonomous District & 8,6 & 11,7 & 10,19 & 10,41 \\
\hline Chelyabinsk region & 1,62 & 1,6 & 1,56 & 1,47 \\
\hline Siberian Federal District & 4,74 & 4,4 & 3,95 & 3,7 \\
\hline Far Eastern Federal District & 6,12 & 5,9 & 5,67 & 5,86 \\
\hline
\end{tabular}

There comes a habit of bad forms of existence. Man falls into the cycle of "dependence" of poor living circumstances of which can not get out on their own.

Since 2014 apartment buildings expected to be repaired by the fund overhaul (FO) or accounts opened with homeowners' associations (HOA). Regional operators are authorized to dispose of these accounts [6].

FO due to the "pocket" of taxpayers and for purpose of expenses can become a full participant in the financial market by analogy with the pension, health, social security funds. Finance management system overhaul consists of two parts: income generation and distribution costs.

Income generation system has three "stumbling block" in the way of practical implementation of the reforms conceived.

1. The process of accumulation of funds for repairs. The principle of "common pot" is contrary to the Civil Code and the Constitution of Russia. Those who have a home in good condition contain their property and other people's property: the funds collected from tenants of a house can go for another overhaul of the strategic plan of repairs. Setting priorities are not standardized for the regions and is "random" nature.

2. Weak control over the formation of the of payment size for overhaul. Governments set limits on the amount of monthly payment to the Major Repair Fund. 
Table 2. The cost of major repairs to 1 sq. meter of housing area in rubles [7]

\begin{tabular}{|l|c|c|}
\hline Regions & $\mathbf{2 0 1 4}$ & $\mathbf{2 0 1 5}$ \\
\hline Moscow & 7,30 & 15,00 \\
\hline Saint Petersburg & 2,00 & $2,00-3,00$ \\
\hline \multicolumn{2}{|c|}{ Ural Federal District } \\
\hline Kurgan region & 6,97 & 6,97 \\
\hline Sverdlovsk region & 6,10 & 8,20 \\
\hline Tyumen region & $5,60-20,11$ & 7,50 \\
\hline Khanty-Mansi Autonomous District & $8,55-13,85$ & $9,10-14,7$ \\
\hline Yamalo-Nenets Autonomous District & 10,50 & 10,50 \\
\hline
\end{tabular}

In urban regions fee overhaul varies greatly. For example, St. Petersburg has a minimal fee. The city is known monuments they repaired at the expense of the federal budget. The minimum rate set in the Sverdlovsk region for 2015-2016 amounts to 8 rubles per sq. $\mathrm{m}$ (Yekaterinburg is 8.52 rubles). This is $23.25 \%$ more than the level of the tariff for 2014 [8, 9].

History of the problem shows that the owners always pay for the overhaul. Only positions in settlement documents from time to time changed the name. For example, in Yekaterinburg in 2003 the position of "Overhaul" was included in "Payment for the maintenance of housing" (1.65 rubles per sq. m). Since March 2004 position "Payment for the maintenance of housing" became known as the "Maintenance" (The rate increased 1.46 times compared to 2003). In early 2008, the position "Maintenance" has teamed up with the position of "property of Contents" and has increased 1.94 times. Merge and rename articles of utility bills has continued since 2004. Thus, the "latent" requisitions for repair turned into millions of rubles, and the public is not exposed the cost of supervision, timing and quality of repairs made. The current situation shows the next fiscal "difficulties" of the program - regional operator of Sverdlovsk region managed to complete major repairs only $30 \%$ of the planned number of houses [10].

In some European countries the fee overhaul was introduced. Various tariff plans have been used. Thus, the inhabitants of one city, living in different houses, pay fees for overhaul at various rates. Residents renovated house pay a smaller amount for it.

The rate laid a systematic approach to the estimation of parameters - design features and the age of the building, the quality of the roof materials, window and door openings. This experience can be of practical interest for the management of municipal services Russia [11]

Table 3. Housing and communal services actually paid by the population, mln rubles [5]

\begin{tabular}{|c|c|c|c|c|c|c|}
\hline Regions & $\mathbf{2 0 0 7}$ & $\mathbf{2 0 0 9}$ & $\mathbf{2 0 1 1}$ & $\mathbf{2 0 1 2}$ & $\mathbf{2 0 1 3}$ & $\mathbf{2 0 1 4}$ \\
\hline $\begin{array}{c}\text { Russian } \\
\text { Federation }\end{array}$ & 722524,5 & 1063282,7 & 1466772,3 & 1533237,1 & 1677213,5 & 1820164,1 \\
\hline $\begin{array}{c}\text { Central } \\
\text { Federal } \\
\text { District }\end{array}$ & 225865,1 & 332734,8 & 460690,7 & 482180,6 & 530352,9 & 577388,9 \\
\hline Moscow & 72965,9 & 103026,8 & 132517,6 & 138448,7 & 154140,6 & 167259,9 \\
\hline $\begin{array}{c}\text { Northwestern } \\
\text { Federal } \\
\text { District }\end{array}$ & 85123,5 & 123479,9 & 179418,5 & 189092,4 & 196528,9 & 220809,7 \\
\hline $\begin{array}{c}\text { Saint } \\
\text { Petersburg }\end{array}$ & 31191,4 & 45720,5 & 68858,1 & 74547,4 & 74811,1 & 92816,3 \\
\hline $\begin{array}{c}\text { Southern } \\
\text { Federal } \\
\text { District (till }\end{array}$ & 74415,9 & & & & \\
\hline
\end{tabular}




\begin{tabular}{|c|c|c|c|c|c|c|}
\hline 2009) & & & & & & \\
\hline $\begin{array}{c}\text { Southern } \\
\text { Federal } \\
\text { District (from } \\
2010 \text { ) }\end{array}$ & & 81770,9 & 112098,7 & 121029,4 & 130694,9 & 146278 , \\
\hline $\begin{array}{c}\text { North } \\
\text { Caucasian } \\
\text { Federal } \\
\text { District }\end{array}$ & & 30506,3 & 43177,4 & 46235,3 & 54993,2 & 57614,5 \\
\hline $\begin{array}{l}\text { Volga Federal } \\
\text { District }\end{array}$ & 136259,2 & 205541,5 & 276353,3 & 287380,4 & 319062,5 & 344207 , \\
\hline $\begin{array}{c}\text { Ural Federal } \\
\text { District }\end{array}$ & 66576,1 & 93040,3 & 131940,7 & 135518,9 & 150343,8 & 162250 , \\
\hline Kurgan region & 3077,6 & 4792,7 & 6624,7 & 6922,9 & 7650,8 & 8162,3 \\
\hline $\begin{array}{l}\text { Sverdlovsk } \\
\text { region }\end{array}$ & 21249,3 & 31106,4 & 46241 , & 48157,5 & 54153,8 & 59832,3 \\
\hline $\begin{array}{l}\text { Tyumen } \\
\text { region }\end{array}$ & 26028 & 35992,5 & 45022,8 & 44992,5 & 49281 , & 52165 \\
\hline $\begin{array}{l}\text { Khanty-Mansi } \\
\text { Autonomous } \\
\text { District }\end{array}$ & 14626,9 & 19762,9 & 25417,5 & 25445,4 & 27349,3 & 28520,3 \\
\hline $\begin{array}{c}\text { Yamalo- } \\
\text { Nenets } \\
\text { Autonomous } \\
\text { District }\end{array}$ & 6025,5 & 8482,1 & 9665,4 & 9371,5 & 9361,4 & 9590,8 \\
\hline $\begin{array}{c}\text { Tyumen } \\
\text { region } \\
\text { (without AD) }\end{array}$ & & & 9939,9 & 10175,5 & & 14053,8 \\
\hline $\begin{array}{l}\text { Tyumen } \\
\text { region (in } \\
\text { part) }\end{array}$ & & 7747,5 & 9939,9 & 10175,5 & 12570,3 & \\
\hline $\begin{array}{l}\text { Chelyabinsk } \\
\text { region }\end{array}$ & 16221,2 & 21148,7 & 34052,2 & 35446 , & 39258,3 & 42090,4 \\
\hline $\begin{array}{l}\text { Siberian } \\
\text { Federal } \\
\text { District }\end{array}$ & 88005,9 & 128842,7 & 171905 & 178239 & 192129,9 & 204469,7 \\
\hline $\begin{array}{c}\text { Far Eastern } \\
\text { Federal } \\
\text { District }\end{array}$ & 46278,7 & 67366,3 & 91187,9 & 93560,9 & 103107,5 & 107146,2 \\
\hline
\end{tabular}

The table shows the amount of payments for housing and communal services taking into account the payment of debt from previous years in the dynamics of the odd years (2007 to 2015).

3. Late payment or refusal to pay contributions for the overhaul.

This problem is related to the relationship of power and property owners. Over the past six months by region swept by a wave of discontent: contributions to overhaul turned the problem of mass non-payment and lawsuits about the validity of the board [12].

Crisis in 2015 reduces the solvency of the population. The risk of unemployment and little income increased the number of "non-payers".

Income distribution system has the risk of misuse of funds, conspiracy irresponsible contractors and "lazy" system placing temporarily free funds.

Temporarily free funds should work for growth. At present time there is not even the interest on the accounts of FO and condominiums even in the amount of a key Bank of Russia. This situation shows the pseudo-effective and can lead to enormous loss of inflation. It is advisable to place a temporary surplus in low-risk financial instruments 
(regional bank deposits). This will increase the lending capacity of regional commercial banks and to increase employment and provide economic development of regions.

Transparency of information on the use of funds and contracting will provide free access to homeowners to electronic resources of the Regional Fund for the Promotion overhaul of the common property.

The question of allocation of temporary free funds remains open. FO accumulate funds in bank accounts (FO Sverdlovsk region began to accumulate funds for the Agricultural Bank account). What lies behind this?

There is a latent additional funding government programs and ensuring the liquidity of the largest banks with state participation, which are financial "safety cushion" of local authorities.

Innovation 2. Licensing management companies (MC).

The introduction of licensing is intended for HCS market clearing of irresponsible management and destruction of the "gray" market. Already in May 2015 monitoring revealed twenty-three "empty" company in Yekaterinburg [13].

Experience has shown that a number of countries (USA, Germany, France, Finland, Poland, Hungary), the licensing administration increased the quality of municipal management. On the housing market only the best companies. In addition, the increased specialization and increased competition between the same specialization of organizations [14]

Browse companies control the licensing procedure in accordance with the law has highlighted the problem of quality control management in the housing sector.

These problems are internal (from the perspective of business processes management companies themselves) and external (from the point of view of the impact of external factors) character.

On the one hand, MC which is in charge of a lot of illiquid housing facilities can throw off this burden from the shoulders and give up to obtain a license. The dilapidated legacy" take yourself municipal budgets. On the other hand, it is easy to obtain a license scheme will wish to establish fraudsters management companies to raise money from the population. Withdrawal of a license - a slow process, during which time the company will provide fraudulent financial "safety cushion".

2014-2015 marked in Yekaterinburg "communal wars" between rival management companies. These events are taking place against the backdrop of awakening civic consciousness owners [15].

An element of the state policy in relation to the MK is the application of penalties for various violations: the concealment of information, fraud in the calculation of rent, violation of the rules of detention houses. These penalties were tightened in 2015. However, the MK is commercial organization and the main purpose is profit, which comes from the "pocket" residents. Accordingly, the penalties - is the hidden fees, included in "maintenance of housing." In addition, the cost of utilities will be included costs for licensing non-core expenses.

Table 4 shows the amount of fines paid to the management companies of Yekaterinburg in 2014 for various violations.

Table 4. Amounts of the fines paid by the housing management companies of Yekaterinburg in 2013 [10]

\begin{tabular}{|c|l|c|}
\hline № & \multicolumn{1}{|c|}{ Management company } & $\begin{array}{c}\text { Amount of fine (Thousand } \\
\text { Roubles) }\end{array}$ \\
\hline 1 & MC Standard / ЗАО «УК Стандарт» & 1935,5 \\
\hline 2 & $\begin{array}{l}\text { МС НС Остуаbrsky district / ООО «УК ЖКХ } \\
\text { Октябрьского района» }\end{array}$ & 818,5 \\
\hline
\end{tabular}




\begin{tabular}{|c|l|c|}
\hline 3 & МС Verkh-Isetskaya / ЗАО «УК Верх-Исетская» & 795,6 \\
\hline 4 & $\begin{array}{l}\text { МС REMР Zheleznodorozhny district / ЗАО «УК РЭМП } \\
\text { Железнодорожного района» }\end{array}$ & 704,9 \\
\hline 5 & Fund Radomir / ООО «Фонд Радомир» & 510,1 \\
\hline 6 & НМС Radomir-Invest / ООО УЖК «Радомир - Инвест» & 411,0 \\
\hline 7 & $\begin{array}{l}\text { НМС Ordzhonikidzevskaya / ЗАО «Орджоникидзевская } \\
\text { УЖК» }\end{array}$ & 381,0 \\
\hline 8 & МС Nizhneisetskaya / ООО «УК Нижнеисетская» & 358,0 \\
\hline 9 & МС REMP UZНSК / «УК РЭМП УЖСК» & 343,0 \\
\hline 10 & МС REMP Elmash / «УК РЭМП - Эльмаш» & 317,0 \\
\hline 11 & $\begin{array}{l}\text { МС НСS Ordzhonikidzevskу district / ООО «УК ЖКХ } \\
\text { Орджоникидзевского района» }\end{array}$ & 282,0 \\
\hline 12 & НМС Ural-ST / ЗАО «УЖК Урал-СТ» & 213,0 \\
\hline 13 & МС Chkalovskaya / «УК Чкаловская» & 199,0 \\
\hline
\end{tabular}

New measures of state influence on the management companies may indirectly contribute to the destruction of competition and redistribution of the housing market in favor of the companies affiliated with the authorities. In practice, this scheme can be implemented as follows: the management company is deprived of the license as prescribed by the state supervisory authority for the poor service $15 \%$ of the total floor area of all buildings served. Then the "objectionable" economic counterparties are removed from the playing field and come into play asset managers, "nurtured" by the authorities.

In the area of control over the activities of management companies are invited to apply the experience of European countries. For example, in Sweden, Italy, the UK is extremely well developed "house" movement with a horizontal structure of relations. Association homeowners monitor tariffs and quality of service. They protect the rights of owners in court.

International Alliance of Inhabitants (IAI) helps citizens in the implementation of social rights. Housing Swedish Court prevents corruption. The tariffs of housing and communal services are transparent. Since 2006, the European people's universities are functioning housing, where the population is trained active government technology [16].

An effective method of improving the financial performance of management companies can act as a requirement to increase the authorized capital, which will not only guarantee the satisfaction of creditors' claims, but will also get an idea of the scale of operations and financial condition of the management company.

As a method of minimizing the risks and at the same time one of the most effective tools of financial stabilization of the management companies can recommend the creation of reserve capital.

As part of the retained earnings capital will guarantee the obligations liquid unforeseen expenses and possible losses. Provisions allow management companies to reserves will increase the stock of financial strength and to reduce operation risks in terms of survival.

Innovation 3. On January 1, 2016 changed the treatment system of waste management, which became known as "utilities" [17]. Regional operators collect and recycle waste.

However, terminological innovation has led to a lack of clear understanding of the definition of "municipal solid waste" left unresolved questions about the guarantees of quality treatment services and the waste of the area of responsibility for servicing them. For example, "without a master" stayed container sites for waste collection.

Problems of waste management, resulting in the "management" of man, put off no longer: it is a question of security of human living in Russian cities. We offer the best experience to appeal to the European Union countries on the collection and disposal system. The most effective system of waste management, improves the environment, there is in Sweden. Burial subjected to only $1 \%$ of the waste, the rest falls into recycling [18]. 
The authors believe that it is necessary to conduct a thorough classification of morphological composition of municipal waste and to allocate clear lines of responsibility of municipal services managers. Urban management is a holistic system. It is impossible to address issues of financial or technological support apart from psychophysical laws of interaction between people in the society. Urban management in Russia is currently showing contradictory results.

Appeal to the experience of effective functioning of the management models do not allow the "roll down" to "false" understanding urbanization as a post-response system of urban management problems. It is today we need the expert judgment of the urban space with its social contrasts and environmental constraints.

\section{References}

1. Unified interdepartmental information and statistical system, http://www.fedstat.ru

2. E. Kondyukova, O. Nikitina et al., Construction economy, 4, 46 (2015)

3. E. Kondyukova, O. Nikitina et al., Construction economy, 2, 14 (2016)

4. Federal Law of 29.12.2014 No. 458-FZ (ed. of 29.12.2015) "On Amendments to the Federal Law" On Production and Consumption Waste", Separate Legislative Acts of the Russian Federation and the Annulment of Certain Legislative Acts (Provisions of Legislative acts) of the Russian Federation" (rev. and ext., joined. in force from 01.01.2016),

http://base.consultant.ru/cons/cgi/online.cgi?req=doc;base=LAW;n=191899; div=LAW ;dst=100004,0;rnd=203280.9831487736089928

5. The Federal State Statistics Service, http://www.gks.ru/

6. Regional Fund to facilitate capital repair of common property in apartment buildings of the Sverdlovsk region, http://www.fkr66.ru

7. Federal Payment Standards of housing and communal services in 2013-2015, Resolution of the Russian Government dated February 21, 2013 No. 146 (repealed), http://base.consultant.ru/cons/cgi/online.cgi?req=doc;base=LAW;n=142431;div=LAW ;dst $=100003,-1 ;$ rnd $=203280.10032736270715814$

8. On establishing in 2014 the minimum fee for the overhaul of the common property in apartment buildings, located on the territory of Sverdlovsk region, Resolution of the Sverdlovsk Region Government No. 1625-PP dated 27.12.2013, http://base.consultant.ru/regbase/cgi/online.cgi?req=doc;base=RLAW071;n=128829; di $\mathrm{v}=\mathrm{LAW} ; \mathrm{dst}=0,0 ; \mathrm{rnd}=203280.8920819437326677$

9. On the establishment the Sverdlovsk Region minimum fee for the overhaul of the common property in apartment buildings on 2015-2017, Resolution of the Sverdlovsk Region Government No. 833-PP dated 10.01.2014, http://base.consultant.ru/regbase/cgi/online.cgi?req=doc;base=RLAW071;n=158401; di $\mathrm{v}=\mathrm{LAW} ; \mathrm{dst}=100003,0 ; \mathrm{rnd}=203280.3387107734360899$

10. Sverdlovsk Government Web-portal, http://www.uralinform.ru

11. Housing and communal services tariffs in the Russian Federation in 2000-2010, Analytic report, Energy and Finance Institute, http://genproc.gov.ru/upload/iblock/a36/bhmyrs_epjuxlazyj\%2014.01.11.doc

12. Web-Portal of federal arbitration courts of the Russian Federation, http://www.arbitr.ru

13. State information system of housing and communal services, http://dom.gosuslugi.ru

14. G. Makarov, Economy and Law, 6 (2011)

15. The web-portal of the Russian Federation Ministry of Construction, http://www.minstroyrf.ru

16. The official website for European Social Forum, http://www.fse-esf.org 
17. The Russian Federation Housing Code of 29.12.2004 No. 188-FZ, http://base.consultant.ru/cons/cgi/online.cgi?req=doc;base=LAW;n=193170;div=LAW ;dst $=100003,1 ; \mathrm{rnd}=203280.4900346251295875$

18. Alternative energy technologies web-site, http://www.alterenergy.info 